\title{
Peningkatan Hasil Pembelajaran Passing Bawah dan Passing Atas Melalui Pendekatan Permainan
}

\author{
Karnoto* \\ SMK Negeri I Dlanggu Mojokerto
}

\section{A R T I C L E I N F O}

Article history:

Received 12 December 2019

Received in revised form

01 January 2020

Accepted 30 January 2020

Available online 27

February 2020

\section{Kata Kunci:}

Peningkatan hasil

pembelajaran, Passing

bawah dan Passing atas,

Pendekatan Permainan

Keywords:

Improved learning

outcomes, Under Pass and

Over Pass, Game

Approach.

\begin{abstract}
A B S T R A K
Tujuan penelitian ini adalah untuk mengetahui apakah pendekatan permainan dapat meningkatan hasil pembelajaran Penjasorkes Materi passing bawah dan passing atas siswa kelas XI SMKN 1 Dlanggu. Pendekatan permaianan merupakan salah satu bentuk model pembelajaran yang tepat, karena menekankan pada pembelajaran rekan sejawat/ teman sendiri untuk mengajari cara melakukan olah raga volly untuk materi passing bawah dengan tujuan memacu semangat siswa untuk dapat meningkatkan motivasi berlatih dan kemampuan menguasai materi passing bawah pada mata pelajaran olah raga. Jenis penelitian ini adalah Penelitian tindakan kelas (PTK). Yang dijadikan subjek dalam penelitian tindakan kelas ini adalah siswa kelas XI ANM 1, dengan jumlah siswa 32 orang yang terdiri dari 17 orang laki-laki dan 15 orang perempuan. Instrumen yang digunakan dalam penelitian ini sebagai alat pengumpulan data, yaitu: instrumen tes, yang terdiri atas: (a)pendekatan permainan, dan (b) tes hasil belajar siswa. Analisis data dilakukan setelah data penelitian terkumpul seluruhnya, baik data yang berasal dari pendekatan permaina maupun Hasil Belajar Siswa, pre-test, maupun post-test. Teknik yang digunakan untuk analisis data pada penelitian ini adalah teknik deskriptif analitik. Hasil penelitian ini menunjukkan bahwa dengan peningkatan hasil pembelajaran passing bawah dan passing atas melalui pendekatan permainan dapat meningkatkan percaya diri siswa. Oleh karena itu siswa diharapkan dapat belajar sambil berlatih tanpa rasa takut lagi dengan bola. Dengan kegiatan ini pula diharapkan kemampuan afekfif, kognitif, dan psikomotorik siswa dapat berkembang lebih baik lagi.
\end{abstract}

A B S T R A C T

The purpose of this study was to determine whether the approach to the game can improve learning outcomes Penjasorkes material under pass and over pass at XI Grade students at SMK 1 Dlanggu. The game approach is a form of learning model that is appropriate, because it emphasizes the learning of peers / friends themselves to teach how to do volleyball for under-passing material with the aim of stimulating students' enthusiasm to be able to increase their motivation to practice and the ability to master under-passing material in the eye sports lessons. This research was Classroom Action Research. The subjects in this class action research were XI Grade ANM 1 students, with 32 students consist of 17 men and 15 women. The instruments used in this study as data collection tools were: test instruments, which consist of: (a) a game approach, and (b) a test of student learning outcomes. Data analysis was carried out after all research data had been collected, both data originating from the game approach and Student Learning Outcomes, pre-test, and post-test. The technique used for data analysis in this study is descriptive analytic technique. The results of this study indicate that by increasing learning outcomes under passing and over passing through the game approach can increase student confidence. Therefore, students are expected to learn while practicing without fear anymore with the ball. With this activity it is also expected that students' affective, cognitive, and psychomotor abilities can develop even better. 


\section{Pendahuluan}

Pendidikan bertujuan untuk mengembangkan segala potensi yang di miliki individu,sehingga dengan potensi tersebut akan bermanfaat bagi dirinya sendiri dan lingkunganya. Sugiharto,dkk (2012:3) menyebutkan bahwa pendidikan adalah suatau usaha yang dilakasanakan secara sadar dan sengaja untuk mengubah tingkah laku manusia baik secara individu maupun kelompok untuk mendewasakan manusia melalui upaya pengajaran dan pelatihan. Secara mendasar hal ini dikemukakan dalam Undang-Undang Bab II Pasal3 mengenai Sistem Pendidikan Nasional Nomor 20 Tahun 2003 tentang tujuanpendidikan bahwa:

"Pendidikan nasional berfungsi mengembangkan kemampuan danmembentuk watak serta peradaban bangsa yang bermartabat dalam rangkamencerdaskan kehidupan bangsa, bertujuan untuk berkembangnya potensipeserta didik agar menjadi manusia yang beriman dan bertakwa kepadaTuhan Yang Maha Esa, berakhlak mulia, sehat, berilmu, cakap, kreatif,mandiri, dan menjadi warga Negara yang demokratis, serta bertanggungjawab".

Pendidikan jasmani merupakan bagian yang intregral dari Sistem Pendidikan nasional secara keseluruhan. Pendidikan jasmani merupakan proses pendidikan yang memanfaatkan aktivitas jasmani yang direncanakan secara sistimatik yang merupakan media untuk mendorong pertumbuhan fisik, perkembangan psikis, keterampilan motorik, pengetahuan dan penalaran, penghayatan nilai-nilai (sikapmental-emosional-sportifitas-spiritual-sosial) serta pembiasaan pola hidup sehat yang bermuara untuk merangsang pertumbuhan dan perkembangan kualitas fisik dan psikis yang seimbang (Depdiknas Nomor 20Tahun 2003).

Pendidikan jasmani olahraga dan kesehatan adalah proses pendidikan menyeluruh yang menggunakan aktifitas fisik dengan permainan dan olahraga sebagai alatnya (Rusli Lutan, 2010: 42). Dengan demikian dapat diartikan bahwa tujuannya bukan sekedar pencapaian yang bersifat fisik semata, akan tetapi juga melibatkan aktifitas psikis. Oleh karena itu penyelenggaraan pendidikan jasmani olahraga dan kesehatan harus dikembangkan lebih optimal sehingga peserta didik lebih inovatif, terampil, kreatif, memiliki kesegaran jasmani dan kebiasaan hidupsehat serta memiliki pengetahuan dan pemahaman gerak manusia.

Pendidikan jasmani merupakan aktifitas olahraga dan kesehatan yang diajarkan di sekolah memiliki peranan sangat penting, memberikan kesempatan kepada siswa untuk terlibat langsung dalam berbagai pengalaman belajar melalui aktivitas jasmani, olahraga harus dilakukan secara sistimatis, diarahkan untuk membina pertumbuhan fisik dan pengembangan psikis yang lebihbaik.Upaya peningkatan kualitas proses pembelajaran Penjasorkes di sekolah belum berjalan sebagaimana yang diharapkan. Hal tersebut dapat dilihat dari pengalaman penulis bahwa peserta didik masih mengalami kesulitan dalam memahami konsep dan penguasaan teknik dasar suatu cabang olahraga, demikian pula guru masih mengalami kesulitan dalam menanamkan konsep dan penguasaan teknik dasar olahraga sehingga berakibat pada rendahnya kemampuan bermain bola voli maupun keterampilan teknik-teknik dasar bola voli.

Ada beberapa faktor yang mempengaruhi keberhasilan proses pembelajaran penjasorkes antara lain: faktor guru, faktor siswa, faktor materi pembelajaran, faktor alat dan fasilitas olahraga, metode pembelajaran, jumlah siswa yang terlalu banyak, serta alokasi waktu yang kurang. Faktor-faktor tersebut merupakan suatu kesatuan yang saling terkait dan tidak dapat dipisahkan satu dengan yang lainnya. Agus S Suryobroto (2014: 1) mengatakan bahwa pembelajaran jasmani dapat berjalan dengan sukses dan lancar ditentukan oleh beberapa unsur antara lain: guru, siswa, kurikulum, sarana prasarana, tujuan, metode, lingkungan yang mendukung, dan penilaian. Masalah yang sering dijumpai oleh guru penjasorkes dalam proses pembelajaran adalah masalah metode pembelajaran. Menggunakan metode pembelajaran yang sesuai dengan materi pembelajaran dapat mengoptimalkan proses pembelajaran penjasorkes di sekolah. Untuk itu guru pendidikan jasmani dituntut kreativitasnya dalam melaksanakan proses pembelajaran penjasorkes yang sesuai dengan kurikulum.

Melihat betapa pentingnya pendidikan jasmani, terutama bagi anak usia pertumbuhan dan perkembangan maka sudah seharusnya pendidikan jasmani diberikan kepada semua tingkat lembaga pendidikan baik dari TK sampai dengan SMA/ SMK karena pada umumnya diusia tersebut anak sedang mengalami proses pertumbuhan dan perkembangan. Kompetensi Inti dalam kurikulum pendidikan jasmani SMK kelas XI yaitu, menyajikan pengetahuan faktual dan konseptual dalam bahasa yang jelas, sistematis, logis dan kritis, dalam karya yang estetis, dalam gerakan yang mencerminkan anak sehat, dan dalam tindakan yang mencerminkan perilaku anak. Sedangkan Kompetensi Dasarnya yaitu, mempraktikkan kombinasi gerak lokomotor, non-lokomotor, dan manipulatif sesuai dengan konsep tubuh, ruang, usaha, dan keterhubungan dalam berbagai permainan bola besar sederhana dan atau tradisional. Materi pembelajaran bola voli ini diberikan kurang lebih 2-3 pertemuan tatap muka.Tehnik 
gerak dasar dalam permainan bola voli merupakan faktor yang sangat penting. Suharno (2018: 51) mengatakan bahwa, penguasaan gerak dasar bermain bola voli merupakan salah satu unsur yang ikut menentukan menang atau kalahnya suatu regu dalam suatu pertandingan di samping unsur kondisi fisik,teknik dan mental. Menurut M. Yunus (2012: 68) teknik dalam permainan bolavoli dapat diartikan sebagai cara memainkan bola secara efektif dan efisien sesuaidengan peraturan-peraturan permainan yang berlaku untuk mencapai suatu hasil yang optimal.Pada permainan bola voli, teknik dasar merupakan faktor yang mendasar yang harus dikuasai oleh siswa SD/MI sampai SMA/SMK. Dengan menguasai teknik dasar bermain bola voli, diharapkan siswa akan memiliki keterampilan bermain bola voli. Menurut pendapat Nuril Ahmadi, (2017: 19). Mengatakan bahwa Permainan bola voli merupakan suatu permainan yang kompleks yang tidak mudah untuk dilakukan setiap orang. Diperlukan pengetahuan tentang teknikteknik dasar dan teknik-teknik lanjutan untuk dapat bermain bola voli secara efektif. Teknik dasar bermain bola voli meliputi passing, service, smash dan block. Passing merupakan teknik dasar bola voli yang berfungsi untuk memainkan bola dengan teman seregunya dalam lapangan permainan sendiri. Disamping itu juga, passing sangat berperan untuk mendukung penyerangan atau smash. Hal ini karena, smash dapat dilakukan dengan baik, jika didukung passing yang baik dan sempurna.Passing bawah merupakan teknik gerak dasar yang paling awal diajarkan bagi siswa atau pemain pemula. Passing bawah dilakukan dengan kedua lengan untuk dioperkan atau dimainkan di lapangan permainan sendiri. Pada gerakan teknik passing bawah melibatkan beberapa gerakan dari anggota badan antaralain: posisi kaki, posisi badan, posisi kedua tangan, dan gerakan lanjut. Bagian bagian tubuh tersebut merupakan rangkaian gerakan passing bawah yang tidak dapat dipisah-pisahkan pelaksanaannya untuk menghasilkan kualitas passing bawah yang baik dan sempurna. Agar siswa mampu melakukan passing bawah dengan baik dan benar harus dilakukan pembelajaran yang sistematis dan terprogram. Seorang guru harus mampu memilih metode yang mudah dipelajari dan dipahami oleh siswa.

Berdasarkan pengamatan yang peneliti lakukan diSMK N I Dlanggu, diketahui permasalahan yang dihadapi oleh guru pendidikan jasmani di SMK N I Dlanggu adalah selain penguasaan gerak dasar yang masih rendah kebanyakan siswa sulit untuk diatur saat pembelajaran, siswa sering melakukan sesuatu sesuai keinginan sendiri tanpa mengindahkan perintah dari guru. Saat melakukan passing bawah hasilnya masih banyak siswa yang salah dalam melakukan gerakannya. Selain itu penggunaan metode pembelajaran yang kurang tepat. Guru penjasorkes mengajar permainan bolavoli dengan menggunakan metode drill atau latihan dalam permainan bola voli.

Pembelajaran permainan bola voli yang seperti itu membuat siswa kurang tertarik sehingga menjadikan siswa menjadi kurang aktif selama proses pembelajaran berlangsung. Untuk menciptakan suasana pembelajaran yang menyenangkan bagi siswa maka perlu adanya metode yang dapat membuat siswa senang belajar, dan mau mengikuti pembelajaran sampai selesai materi.

Pembejaran passing bawah yang dilakukan selama ini belum dapat meningkatkan motivasi siswa. Siswa akan berhasil dalam pembelajaran passing bawah dan Passing atas, jika termotivasi untuk mempelajari gerakan-gerakan passing bawah dan passing atas. Untuk meningkatkan motivasi siswa maka perlu adanya metode yang tepat, sehingga siswa tidak mengalami kejenuhan. Namun selama ini belum pernah diterapkan metode yang bervariatif oleh guru.Untuk mencapai tujuan pembelajaran, seorang guru harus kreatif dalam menyajikan materi pembelajaran dengan berbagai cara agar bahan pelajaran yangdisajikan dapat diterima dengan baik oleh siswa. Anggapan Moston yang dikutip oleh Agus S. Suryobroto (2014: 38-39) bahwa "Mengajar adalah serangkaian hubungan yang berkesinmbungan antara guru dengan siswa, yaitu: (1) mencoba mencapai keserasian antara apa yang diniatkan dengan apa yang sebenarnya terjadi, (2) masalah yang bertentangan dengan metode mengajar."Pembelajaran bola voli harus dilaksanakan dengan langkah-langkah yang benar dan tentunya diperlukan program perencanaan dan metode yang benar pula, sehingga tujuan pembelajaran dapat dicapai dengan optimal. Namun, untuk meraih itu semua banyak faktor yang mempengaruhi keberhasilan pembelajaran sehingga harapan yang diinginkan tidak mudah untuk diwujudkan.

Belajar adalah suatu proses yang komplek yang terjadi pada semua orang dan berlangsung seumur hidup sejak dini masih bayi sehingga keliang lahad nanti, salah satu pertanda bahwa seseorang telah belajar sesuatu adalah adanya perubahan tingkahlaku dalam dirinya. Perubahan yang bersifat pengetahuan (kognitif) dan keterampilan (psikomotor) maupun yang menyangkut nilai sikap dan disiplin, keberhasilan belajar merupakan tujuan harapan dan tujuan utama dalam pelaksanaan proses belajar mengajar yang dikembangkan oleh guru baik di sekolah maupun di luar sekolah merupakan yang sangat terpuji bila seorang guru. Sehubungan dengan itu guru diharapkan mampu menghubungkan materi yang diajarkan dengan situasi dunia nyata siswa, mendorong siswa membuat hubungan antara pengetahuan dipelajari dengan kehidupan mereka sehingga siswa lebih tertarik untuk meningkatkan pembelajaran passing bawah dan passing atas pada akhirnya akan meningkatkan hasil belajarnya. 


\section{Metode}

Kegiatan yang dilakukan oleh peneliti pada tahap perencanaan adalah: 1) Peneliti melakukan analisis kurikulum untuk menentukan standar kompetensi dan kompetensi dasar yang disampaikan kepada siswa dengan menggunakan pembelajaran dengan media permainan; 2) Membuat RPP siklus I dengan model pembelajaran dengan pendekatan permainan; 3) Membuat lembar observasi siklus I untuk melihat bagaimana kondisi belajar mengajar dikelas ketika latihan dan kerja kelompok dilaksanakan; 4) Membuat Lembar Kerja Siswa siklus I; 5) Membentuk kelompok yang bersifat heterogen baik dari segi kemampuan akademis, jenis pembelajaran dengan menggunakan media interaktif pada siklus I; 6) Menyusun alat evaluasi pembelajaran berdasarkan perkembangan untuk dilaksanakan pada siklus II serta menyiapkan instrumen pendukung pembelajaran lainnya.

Latar penelitian adalah tempat yang digunakan dalam melakukan penelitian untuk memperoleh data yang diinginkan. Dalam Penelitian ini, latar penelitiannya adalah di SMKN 1 Dlanggu Kabupaten Mojokerto.

Penelitian tindakan kelas ini dilaksanakan secara di SMKN 1 Dlanggu. Yang dijadikan subjek dalam penelitian tindakan kelas ini adalah siswa kelas XI ANM 1, dengan jumlah siswa 32 orang yang terdiri dari 17 orang laki-laki dan 15 orang perempuan.

Sebelum penelitian tindakan kelas ini dilakukan, peneliti melakukan persiapan berupa kegiatan-kegiatan sebagai berikut :

a. Studi awal tentang pelaksanaan peningkatan keaktifan siswa dalam pembelajaran Penjasorkes siswa kelas XI ANM 1.

b. Mengidentifikasi permasalahan dalam pelaksanaan peningkatan keaktifan siswa dalam pembelajaran Penjasorkes siswa kelas XI ANM 1.

c. Merencanakan rencana penelitian, pada tahap ini peneliti menyusun serangkaian kegiatan secara menyeluruh berupa siklus-siklus tindakan kelas meliputi peningkatan keaktifan siswa dalam pembelajaran Penjasorkes meliputi peningkatan keaktifan siklus I dan II.

d. Menyusun instrumen sebagai pedoman observasi terhadap pelaksanaan keaktifan siswa kelas XI ANM 1 mengikuti pembelajaran Penjasorkes dalam penelitian tindakan kelas.

e. Penyusunan indikator keberhasilan pendekatan permainan yang berupa keaktifan siswa kelas XI ANM 1 dalam setiap pembelajaran Penjasorkes

Dalam penelitian ini digunakan satu jenis instrumen penelitian sebagai alat pengumpulan data, yaitu: instrumen tes, yang terdiri atas: (a)pendekatan permainan, dan (b) tes hasil belajar siswa.

a. Instrumen Model Pembelajaran

Dalam penelitian ini, instrumen digunakan untuk menentukan tipe model pembelajaran yang sesuai dalam proses belajar mengajar. Instrumen berbentuk tes objektif pilihan ganda dengan dua alternatif jawaban sebanyak 20 butir soal.

b. InstrumenHasil Belajar Siswa

Instrumen tes digunakan untuk mengukur variabel hasil belajar siswa. Instrumen tes ini berbentuk tes objektif pilihan ganda dengan 5 (lima) alternatif jawaban sebanyak 20 butir soal. Instrumen tes ini dikembangkan sendiri oleh peneliti.

Instrumen tes dalam penelitian ini dibedakan menjadi dua, yaitu: instrumen pre-test dan post-test. Tujuannya untuk mengetahui kemampuan yang telah siswa miliki sebelum dan setelah mendapatkan perlakuan. Soal post-test dibuat sama dengan soal pre-test, tetapi dengan urutan nomor butir soal yang diubah.

Penelitian ini dilandasi prinsip kolaboratif dan kooperatif, sehingga penyiapan partisipaan dipandang perlu dilakukan pada kegiatan awal. Melakukan diskusi dengan teman sejawat guru penjasorkes tentang desain atau strategi pembelajaran pada materi passing bawah dan passing atas yang diikuti dengaan penyusunan rencana kegiatan.

Agar penelitian ini berjalan dengan baik sesuai dengan yang diharapkan maka peneliti bersama teman sejawat dan partisipan melakukan pelatihan dan simulasi pembelajaran dengan menggunakan media pembelajaran permaianan sehingga pada pelaksanaan pembelajaran dan penelitian tidak ada kesalahpahaman dan perbedaan persepsi yang berkenaan dengan prosedur, proses pembelajaran yang sedang dilakukan penelitian. 


\section{Hasil dan Pembahasan}

\section{A. Paparan Hasil Observasi Pra-siklus}

Data hasil pretes kelompok siswa sebelum mendapat Pembelajarandengan menggunakan pendekatan permaianan, dianalisis dengan untuk mengetahui tingkat pengetahuan dan pemahaman tentang materi belajar yang berhubungan dengan passing bawah dan passing atas.

Tabel 1. Hasil Belajar Siswa Pra Siklus

\begin{tabular}{|c|c|c|}
\hline No. & Materi Ajar & Rata-rata Nilai \\
\hline 1 & Passing Bawah & 69,00 \\
\hline 2 & Passing Atas & 69,85 \\
\hline & Rata-rata nilai & 69,425 \\
\hline
\end{tabular}

Berdasarkan isi Tabel 1. terlihat bahwa nilai pretes kelompok siswa sebelum mendapat perlakuan pembelajaran dengan pendekatan permainan adalah 69,425.

\section{B. Paparan Hasil Tindakan Siklus 1}

\section{Perencanaan Tindakan Siklus 1}

Perencanaan di mulai dengan membentuk kelompok diskusi. Siswa yang berjumlah 32 siswa dibagi menjadi 5 kelompok sehingga masing-masing kelompok berjumlah 7 siswa. Materi pelajaran yang diajarkan pada siklus I ini adalah pokok bahasan passing bawah dan passing atas Proses pembelajaran ini menggunakan pendekatan permainan yang diterapkan oleh guru secara langsung dalam pembelajaran di lapangan.

Kegiatan yang dilakukan oleh peneliti pada tahap perencanaan adalah:

a. Peneliti melakukan analisis kurikulum untuk menentukan standar kompetensi dan kompetensi dasar yang disampaikan kepada siswa dengan menggunakan pembelajaran dengan pendekatan permainan Membuat RPP siklus I dengan model pembelajaran dengan pendekatan permainan.

b. Membuat lembar observasi siklus I untuk melihat bagaimana kondisi belajar mengajar dikelas ketika latihan dan kerja kelompok dilaksanakan.

c. Membuat Lembar Kerja Siswa siklus I

d. Membentuk kelompok (terdiri dari 5 siswa) yang bersifat heterogen baik dari segi kemampuan akademis, jenis pembelajaran dengan pendekatan permainan pada siklus I

e. Menyusun alat evaluasi pembelajaran berdasarkan perkembangan pada siklus II serta menyiapkan instrumen pendukung pembelajaran lainnya.

\section{Pelaksanaan Tindakan Siklus 1}

Pelaksanaan kegiatan belajar mengajar pembelajaran dengan pendekatan permainan untuk siklus I dengan jumlah siswa 32 siswa. Dalam hal ini Peneliti bertindak sebagai guru. Pengamatan (observasi) dilaksanakan bersamaan dengan pelaksanaan pembelajaran. Pelaksanaan tindakan siklus I dapat diuraikan sebagai berikut:

a. Guru mengawali pembelajaran dengan mengucapkan salam dan menanyakan jumlah siswa yang hadir.

b. Guru melaksanakan apersepsi.

c. Guru membagi siswa dalam kelompok diskusi, kemudian memberi tugas yang berkaitan dengan penggunaan pembelajaran pendekatan permainan.

d. Guru memberi tugas kepada siswa untuk mempresentasikan di depan kelas hal-hal yang berkaitan dengan passing bawah dan passing atas dengan menggunakan pembelajaran pendekatan permainanL, waktu untuk presentasi adalah 3 menit untuk masing-masing individu

e. Guru menindaklanjuti pembelajaran itu dengan menerangkan materi pelajaran tentang hal-hal yang berkaitan dengan passing bawah dan passing atas menggunakan pembelajaran pendekatan permainan, waktu yang digunakan selama 10 menit.

f. Guru bersama-sama siswa mendemonstrasikan penggunaan pembelajaran pendekatan permaianan materi passing bawah dan passing atas . selama 10 menit.

g. Guru bersama-sama siswa melukukan kegiatan pemanasan dengan materipassing bawah dan passing atas. 
h. Guru memberikan tugas secara individu selama 15 menit

i. Guru menutup pelajaran dengan mengucapkan salam.

Dalam siklus pertama ini, berdasarkan catatan peneliti, siswa masih kurang dapat bekerja sama, kerja kelompok masih kurang dapat berjalan sebagaimana yang diharapkan, presentasi belum banyak mendapat perhatian/tanggapan dari pendengar (siswa dari kelompok lain).

\section{Hasil Tindakan Siklus 1}

Selama pembelajaran berlangsung dilakukan observasi untuk mengetahui pengaruh kegiatan pembelajaran dalam meningkatkan hasil belajar siswa dalam pendekatan permainan dengan materi passing atas dan passing bawah Pada pembelajaran ini siswa yang masuk sebanyak 32 siswa.

Guru mengamati, ternyata pada setiap kelompok masih didapati siswa yang kurang memperhatikan pelajaran yang berkaitan dengan passing bawah dan passing atas dan masih berbicara dengan teman didekatnya tentang hal-hal yang tidak berkaitan dengan materi pembelajaran. Melalui serangkaian pertanyaan yang disampaikan kepada siswa, sebagian diantaranya belum memahami dan bahkan tidak tau apa yang di diskusikan dalam kelompoknya. berikut:

Adapun hasil belajar siswa setelah kegiatan yang diberikan dalam Siklus I, dapat dilihat di

Tabel 2. Hasil Belajar Siswa dalam Siklus 1

\begin{tabular}{clcc}
\hline No & \multicolumn{1}{c}{ Nama Siswa } & Nilai & Predikat \\
\hline 1 & Akmad Bayu Sabdo Widodo & 80 & Tuntas \\
2 & Akbar Nur Rokhim & 70 & Tuntas \\
3 & Anisa Firdaus & 70 & Tuntas \\
4 & Arga Eka Prasetya & 80 & Tunas \\
5 & Arnetta Gadis Fania & 60 & Belum Tuntas \\
6 & Awan Satriani Andetama & 60 & Belum Tuntas \\
7 & Desi Fitriani & 70 & Tuntas \\
8 & Dewa Array Dwiyanto & 80 & Tuntas \\
9 & Dewi Farnia & 50 & Belum Tuntas \\
10 & Dinda Puspita Yani & 60 & Belum Tuntas \\
11 & Ela Ayu Anggraeni & 70 & Tuntas \\
12 & Elmo Rizky Alkautsar & 70 & Tuntas \\
13 & Hafidz Mochammad Rizaldi & 90 & Belum Tuntas \\
14 & Hanuun Diya Nida & 60 & Belum Tuntas \\
15 & Intan Safira Duwi Elinda & 75 & Tuntas \\
16 & Ipung Aditya Putra & 70 & Tuntas \\
17 & Kurniawati & 60 & Belum Tuntas \\
18 & Latifah Latul Hanum & 80 & Tuntas \\
19 & Lisdya Indri Famela & 60 & Belum Tuntas \\
20 & M. Zainur Rizal & 90 & Tuntas \\
21 & Maslikhatin Nasrillah.. & 80 & Tuntas \\
22 & Miya Amiliyahi & 60 & Belum Tuntas \\
23 & Mochammad Bagas Setiawan & 60 & Belum Tuntas \\
24 & Mohamad Ilham & 80 & Tuntas \\
25 & Mukhamad Roy Feri & 60 & Belum Tuntas \\
26 & Nur Quwaida & 80 & Tuntas \\
27 & Putrarafiqul Alam & 60 & Belum Tuntas \\
28 & Putri Ayu Rahmadania & 70 & Tuntas \\
29 & Retno Ayu Dalimas & 80 & Tuntas \\
30 & Rizki Akbar Fianto & 70 & Tuntas \\
31 & Vena Asturi & 80 & Tuntas \\
32 & Yenny Dwi Wulandari & 70 & Tuntas \\
\hline & & $\mathbf{2 4 6 0}$ & \\
\hline & & $\mathbf{7 0 . 2 8}$ & \\
\hline
\end{tabular}


Dari tabel di atas dapat diketahui bahwa dengan menerapkan pembelajaran pendekatan pembelajaran pendekatan permaianan tampak bahwa nilai rata-rata siswa adalah 70,28 dengan nilai terendah 5 dan nilai tertinggi 9. Nilai ketuntasan belajar adalah 7,0 jumlah siswa yang mendapat nilai $\geq$ 7,0 sebanyak 21 siswa,yang berarti $60 \%$ dari sejumlah 35 siswa memiliki nilai di atas taraf penguasaan konsep yang diberikan, lebih kecil dari persentase ketuntasan yang dikehendaki yaitu sebesar $95 \%$. Hal ini disebabkan karena siswa masih baru dan asing terhadap metode baru yang diterapkan dalam proses belajar mengajar. Sehingga dapat dikatakan siswa belum banyak memahami tentang konsep pokok bahasan yang dibahas.

\section{Refleksi Tindakan Siklus 1}

Dalam pelaksanaan kegiatan belajar mengajar pada siklus I yang masih terdapat kekurangankekurangan, Maka perlu adanya revisi untuk dilakukan pada siklus II antara lain :

a. Guru dalam memotifasi siswa hendaknya dapat membuat siswa lebih termotivasi selama proses belajar mengajar berlangsung.

b. Guru harus lebih dekat dengan siswa sehingga tidak ada perasaan takut dalam diri siswa, sehingga siswa lebih berkosentrasi dalam pembelajaran.

c. Guru harus lebih bersabar dalam membimbing siswa berdiskusi untuk menemukan hal-hal baru yang berkaitan dengan materi pembelajaran.

d. Guru secara intensif memberikan pengertian kepada siswa kondisi dalam berkelompok, kerjasama kelompok, dan keikutsertaan siswa dalam kelompok.

e. Guru mengubah jumlah siswa (dari 7 siswa menjadi 5 siswa) dalam satu kelompok.

f. Guru membantu kelompok yang belum memahami langkah-langkah pembelajaran pendekatan pembelajaran permainan.

g. Guru memberikan dorongan dan motivasi kepada siswa untuk lebih aktif mencari sumber belajar, diharapkan agar siswa memperoleh hasil yang diharapkan.

\section{Paparan Hasil Tindakan Siklus II}

\section{Perencanaan TindakanSiklus II}

Perencanaan di mulai dengan membentuk kelompok diskusi.Siswa yang berjumlah 32 siswa dibagi menjadi 7 kelompok sehingga masing-masing kelompok berjumlah 5 siswa. Materi pelajaran yang diajarkan pada siklus II ini tetap pada pokok bahasanpassing bawah dan passing bawah. Proses pembelajaran pokok bahasan ini menggunakan pendekatan permainan. yang diterapkan oleh guru secara langsung dalam pembelajaran di kelas.

Kegiatan yang dilakukan oleh peneliti pada tahap perencanaan pada siklus II adalah:

a. Peneliti melakukan analisis kurikulum untuk menentukan Standar Kompetensi dan Kompetensi Dasar yang disampaikan kepada siswa dengan menggunakan pendekatan permainan.

b. Membuat RPP dengan model pembelajaran pendekatan permaianan siklus II

c. Membuat lembar observasi siklus II untuk melihat bagaimana kondisi belajar mengajar di kelas ketika latihan dan kerja kelompok dilaksanakan.

d. Membuat Lembar Kerja Siswa siklus II

e. Membentuk kelompok (terdiri dari 5 siswi) yang bersifat heterogen baik dari segi kemampuan akademis,dengan menggunakan pembelajaran pendekatan permainan pada siklus II.

f. Menyusun alat evaluasi pembelajaran berdasarkan perkembangan pada siklus II serta menyiapkan instrumen pendukung pembelajaran lainnya

\section{Pelaksanaan Tindakan Siklus II}

Pelaksanaan kegiatan belajar mengajar dengan model pembelajaran pendekatan permainan.untuk siklus II dilaksanakan di kelas XI ANM 1 SMKN 1 Dlanggu dengan jumlah siswa 32. siswi materi passing bawah dan passing atas. Dalam hal ini Peneliti bertindak sebagai guru. Pengamatan (observasi) dilaksanakan bersamaan dengan pelaksanaan pembelajaran. Pelaksanaan tindakan disesuaikan dengan RPP (Rencana Pelaksanaan Pembelajaran) dan lembar kerja yang telah dibuat dan mengacu pada revisi siklus I, sehingga kekurangan-kekurangan pada siklus I tidak terulang pada siklus II. Adapun proses belajar mengajar mengacu pada rencana pembelajaran yang telah dipersiapkan dengan menggunakan pembelajaran permainan, dengan tahapan, presentasi kelas, kerja kelompok, tes individu,dan penghargaan kelompok. 
Pelaksanaan tindakan siklus II dapat diuraikan sebagai berikut:

a. Guru mengawali pembelajaran dengan mengucapkan salam dan menanyakan jumlah siswa yang hadir.

b. Guru melaksanakan apersepsi.

c. Guru membagi siswa dalam kelompok diskusi, kemudian memberi tugas yang berkaitan dengan penggunaan model pembelajaran Permainan.

d. Guru memberi tugas kepada siswa untuk mempresentasikan di depan kelas hal-hal yang berkaitan passing bawah passing atas dengan menggunaan model pembelajaran Permainan, waktu untuk presentasi adalah 3 menit untuk masing-masing kelompok.

e. Guru menindaklanjuti pembelajaran itu dengan menerangkan materi pelajaran tentang hal-hal yang berkaitan dengan passing bawah dan passing atas menggunakan model pembelajaran permainan, waktu yang digunakan selama 10 menit.

f. Guru bersama-sama siswa mendemonstrasikan penggunaan permainan materi passing bawah dan passing atas selama 10 menit.

g. Guru bersama-sama siswa melukukan pembelajaran dengan materi passing bawah dan passing atas.

h. Guru memberikan tugas secara individu selama 15 menit

i. Guru menutup pelajaran dengan mengucapkan salam.

\section{HasilTindakan Siklus II}

Selama pembelajaran berlangsung dilakukan observasi untuk mengetahui penerapan Permainandalam meningkatkan hasil belajar siswa dalam proses pembelajaran materi passing bawah dan passing atas. Pada pembelajaran ini siswa yang masuk sebanyak 32. siswa.

Bila dilihat dari angka aktivitas guru dan siswa selama kegiatan belajar mengajar, maka secara keseluruhan aktivitas guru dan siswa menunjukkan pembelajaran yang berorientasi pendekatan keterampilan proses dalam setting pembelajaran pendekatan pembelajaran permainan berpusat pada siswa, dimana siswa terlibat aktif dalam pembelajaran.

Pada akhir proses belajar mengajar siklus II siswa diberi tes dengan tujuan untuk mengetahui tingkat keberhasilan siswa dalam proses belajar mengajar yang sudah dilakukan di siklus I, kemudian dikomparasikan dengan hasil pada siklus II .

Dalam pembelajaran siklus II, konsep-konsep yang teridentifikasi dikembangkan lebih lanjut. Dalam Siklus II ini, berdasarkan catatan peneliti, kerjasama siswa sudah berjalan dengan baik, sehingga masing-masing siswa dapat memecahkan masalah secara individual. Adapun data hasil tes pada siklus II adalah sebagai berikut:

Tabel 3. Nilai Tes Formatif Siswa dalam Siklus 2

\begin{tabular}{clcc}
\hline No & \multicolumn{1}{c}{ Nama Siswa } & Nilai & Predikat \\
\hline 1 & Akmad Bayu Sabdo Widodo & 80 & Tuntas \\
2 & Akbar Nur Rokhim & 70 & Tuntas \\
3 & Anisa Firdaus & 80 & Tuntas \\
4 & Arga Eka Prasetya & 90 & Tunas \\
5 & Arnetta Gadis Fania Elmiansyah & 80 & Tuntas \\
6 & Awan Satriani Sandetama & 80 & Tuntas \\
7 & Desi Fitriani & 80 & Tuntas \\
8 & Dewa Array Dwiyanto & 90 & Tuntas \\
9 & Dewi Farnia & 60 & Belum Tuntas \\
10 & Dinda Puspita Yani & 90 & Tuntas \\
11 & Ela Ayu Anggraeni & 80 & Tuntas \\
12 & Elmo Rizky Alkautsar & 75 & Tuntas \\
13 & Hafidz Mochammad Rizaldi & 70 & Tuntas \\
14 & Hanuun Diya Nida & 90 & Tuntas \\
15 & Intan Safira Duwi Elinda & 80 & Tuntas \\
16 & Ipung Aditya Putra & 80 & Tuntas \\
17 & Kurniawati & 70 & Tuntas \\
18 & Latifah Latul Hanum & 80 & Tuntas \\
19 & Lisdya Indri Famela & 90 & Tuntas \\
20 & M. Zainur Rizal & 80 & Tuntas \\
21 & Maslikhatin Nasrillah.. & 80 & Tuntas \\
22 & Miya Amiliyahi & 90 & Tuntas \\
\hline
\end{tabular}




\begin{tabular}{rlcc}
\hline No & \multicolumn{1}{c}{ Nama Siswa } & Nilai & Predikat \\
\hline 23 & Mochammad Bagas Setiawan & 60 & Belum Tuntas \\
24 & Mohamad Ilham & 90 & Tuntas \\
25 & Mukhamad Roy Feri Ferdhiyanto & 80 & Tuntas \\
26 & Nur Quwaida & 80 & Tuntas \\
27 & Putrarafiqul Alam & 80 & Tuntas \\
28 & Putri Ayu Rahmadania & 90 & Tuntas \\
29 & Retno Ayu Dalimas & 90 & Tuntas \\
30 & Rizki Akbar Fianto & 80 & Tuntas \\
31 & Vena Asturi & 79 & Tuntas \\
32 & Yenny Dwi Wulandari & 80 & Tuntas \\
\hline \multicolumn{2}{r}{ Jumlah } \\
\hline \multicolumn{2}{r}{ Rata-Rata } \\
\hline
\end{tabular}

Dari tabel di atas tampak bahwa hasil nilai evaluasi rata-rata siswa secara individual adalah 80,4 dengan nilai terendah 60 dan nilai tertinggi 90. Data diatas menunjukkan bahwa pada siklus II ini, nilai siswa secara individual mengalami peningkatan, yaitu siswa yang tuntas sebanyak 29 siswa dan yang belum tuntas sebanyak 3 siswa, yang berarti 95\% dari sejumlah 32 siswa memiliki nilai di atas taraf penguasaan konsep yang diberikan. Dari siklus 2 ini dapat dikatakan bahwa proses pembelajaran dengan model pembelajaran pendekatan pembelajaran permainan dapat meningkatkan hasil belajar siswa.

\section{RefleksiTindakan Siklus II}

Dalam pelaksanaan kegiatan belajar mengajar pada siklus II ini masih terdapat kekurangankekurangan. Pada tahap ini akan merefleksikan kembali apa yang telah dilaksanakan selama penelitian tindakan kelas dilakukan. Dari data yang diperoleh dapat diuraikan sebagai berikut:

a. Selama proses belajar mengajar guru telah melaksanakan pembelajaran dengan cukup baik dengan metode pembelajaran pendekatan pembelajaran Permainan, meskipun ada beberapa bagian yang masih belum sempurna, tetapi presentasi pelaksanaan untuk masing-masing kegiatan sudah cukup baik.

b. Berdasarkan data hasil lembar observasi kegiatan kelompok siswa, diadakan perubahan jumlah kelompok pada siklus I sebanyak 7 siswa, dan pada siklus II sebanyak 3 siswa.

c. Kekurangan pada siklus I diperbaiki, sehingga pembelajaran menjadi lebih baik pada siklus II.

d. Hasil evaluasi siswa mengalami peningkatan dari siklus I ke siklus II,dan telah mencapai ketuntasan belajar pada siklus II ini sesuai yang diharapkan yakni peningkatan hasil belajar siswa.

\section{Pembahasan Antar Siklus}

Sebelum perlakuan diberikan pada masing-masing kelompok, nilai rerata pretes siswa sebelum diberi perlakuan pembelajaran dengan Permainan adalah 69,425.Setelah siswa diberi perlakuan pembelajaran dengan Permainanpada siklus I mengalami peningkatan menjadi 70.28, namun hasil ini belum memenuhi target hasil belajar siswa mata pelajaran Penjas orkes yaitu 95\% .

Bila dihitung berdasarkan nilai rerata pretes, kelompok siswa yang diberi perlakuan pembelajaran dengan Permainanseelah dilaksanaknnya siklus ke II mengalami peningkatan rerata hasil belajar sebesar $80,400-69,425=10,975$.

Berdasarkan hasil pada sisklus penelitian tersebut di atas, dapat ditunjukkan bahwa adaperbedaan hasil belajar passing atas dan passing bawah antara siswa yang diajar menggunakan metode pembelajaran dengan dibantu model pembelajaran Permainan.

Hasil penelitian ini juga didukung oleh hasil penelitian Nugraheni (2012) yang menyatakan bahwa ada perbedaan hasil belajar siswa yang yang mendapat perlakuan pembelajaran dengan model pembelajaran Permainan memperoleh rata-rata nilai sebesar 80,400, lebih tinggi daripada sebelum siswa diajar dengan model pembelajaran lainnya, yaitu 69,425

Penerapan pembelajaran dengan Permainan memberikan peningkatatan yang lebih baik pada perolehan hasil belajar passing bawah dan passing atas daripada penerapan pembelajaran dengan metodelainya. Dengan kata lain dapat diinterpretasikan bahwa penerapan pembelajaran dengan permainan dapat meningkatkan perolehan hasil belajar siswa pada materi passing bawah dan passing atas daripada dengan model pembelajar. 


\section{Simpulan dan Saran}

Penerapan pembelajaran dengan pendekatan Permainan memberikan peningkatatan yang lebih baik pada perolehan hasil belajar Penjasrkes materi passing bawah dan passing atas daripada penerapan pembelajaran dengan metodel lainya. Dengan kata lain dapat diinterpretasikan bahwa penerapan pembelajaran dengan pendekatan permainan dapat meningkatkan perolehan hasil belajar siswa pada materi passing bawah dan passing atas daripada dengan model pembelajaran lainnya. Hal ini berdasarkan nilai rerata pretes dimana rata-rata hasil belajar siswa sebesar 69,425, sedangkan setelah siswa diberi perlakuan pembelajaran dengan pendekatan permainan setelah dilaksanaknnya siklus ke II mengalami peningkatan rerata hasil belajar sebesar 80,400 artinya terjadi peningkatan rerata hasil belajar siswa sebesar 10,975 .

Selanjutnya saran yang dapat diberikan yaitu: 1) Hendaknya guru mampu menciptakan suasana kelas yang kondusif sehingga siswa tidak merasa takut; 2) Sebelum melaksanakan pembelajaran hendaknya guru mempersiapkan terlebih dahulu bahan dan alat pembelajaran demi kelancaran kegiatan; 3) Sebelum melakukan pembelajaran di kelas, Guru mampu melakukan setting kelas sesuai rencana; 4) Hendaknya guru melaksanakan model pembelajaran berbasis Permainan secara konsisten. Dengan demikian diharapkan hasil belajar siswa akan lebih meningkat; 5) Hendaknya guru mengadakan kegiatan refleksi dengan guru lain dalam wadah MGMP tentang berbagai masalah pembelajaran dengan penggunaan strategi permainan yang dilakukan sehari-hari; 6) Hendaknya kepala sekolah mendukung penuh dan memberikan motivasi kepada para guru untuk selalu melaksanakan Permainan. guna meningkatkan hasil belajar siswa.

\section{Daftar Rujukan}

Agus S. Suryobroto. (2004). Diktat Mata Kuliah Sarana dan Prasarana Pendidikan Jasmani. Yogyakarta: FIK-UNY.

Aip Syarifuddin, (1992). Pendidikan Jasmani dan Kesehatan. Jakarta: Departemen Pendidikan dan Kebudayaan.

Barbara L. Viera, MS; Bonnie Jill Ferguson, MS. (2004). Bola Voli Tingkat Pemula. (Alih Bahasa: Monti) Jakarta: Dahara Prize Semarang

BSNP (2007). Kurikukum Tingkat Satuan Pendidikan. Jakarta : BSNP

Depdiknas. (2003). UU RI No. 20 Tahun 2003. Sistem Pendidikan Nasional. Jakarta : Asa Mandiri .

L. Viera, Barbara dan Bonnie Jill Fergusson.(2004).Bola Voli Tingkat Pemula. Jakarta: PT RajaGrafindo Persada.

M. Sobry Sutikno, (2009). Belajar Pembelajaran. Prospeet. Bandung.

M. Yunus. (1992). Olahraga Bola Voli. Jakarta : Departmen Pendidikan dan Kebudayaan

Martinis Yamin. (2005). Strategi Pembelajaran Berbasis Kompetensi. Ciputat: Gaung Persada Press.

Muhajir, Pendidikan Jasmani (tiori dan Praktek), Penerbit Erlangga PT. Graha Aksara Pratama

Nuril, Ahmadi. (2007). Panduan Olahraga Bola Voli.Surakarta: Era Pustaka Utama.

Rusli Lutan. (2000). Asas-Asas Pendidikan Jasmani Pendekatan Pendidikan Gerak di Sekolah Dasar. Jakarta: Direktorat Jenderal Olahraga.

Sugihartono, dkk. (2012). Psikologi Pendidikan.Yogyakarta: UNY PresSuharno, H.P. (1981). Metodik Melatih Permainan Bola Volley. Yogyakarta: IKIP Yogyakarta. 